\title{
PIOTR KARWASIŃSKI
}

Redefining the academic library: managing the migration to digital information services, Washington, D.C.: The Advisory Board Company 2011, ss. 80

W bibliotekach akademickich nadchodzi kolejna rewolucja. Zdanie, które jeszcze kilka lat temu $\mathrm{z}$ powodzeniem mogłoby posłużyć jako slogan reklamowy - powoli przestaje zaskakiwać. Od wdrożenia kilkanaście lat temu komputeryzacji - zmieniło się praktycznie wszystko, począwszy od strategii zarządzania i dostosowywania struktury organizacyjnej do nowych funkcji i zadań, poprzez instalację sprzętu informatycznego, a skończywszy na zasadach codziennej pracy bibliotekarzy $w$ systemie bibliotecznym. Dziś gromadzoną literaturę rejestruje się komputerowo, opracowania metadanych dokonuje się w specjalnych edytorach, zaś liczba wdrożonych przez bibliotekę usług elektronicznych świadczy o jej nowoczesności, innowacyjności. Kilkanaście lat funkcjonowania bibliotek hybrydowych w Polsce upłynęło również na obserwowaniu rozwiązań zachodnich i próbie ich implementacji. Z jednej strony $w$ bibliotekach gromadzone są bogate kolekcje zasobów elektronicznych światowych wydawców, z drugiej wdrażane usługi zdalnych zamówien, rezerwacji, prolongat, systemów RFID, platform wirtualnej komunikacji pokazują że nie ma rozwiązań technologicznych, które nie byłyby znane na gruncie polskim. Jednak rozwój usług, pojawianie się nowych nośników informacji elektronicznej, szeroko pojęta komercjalizacja wiedzy oraz zmieniająca się typologia użytkownika biblioteki akademickiej - zwiastują nadejście nowej ery w bibliotekarstwie. Niezwykle ciekawym opracowaniem wieszczącym przyszłość bibliotek akademickich jest bardzo szeroka analiza badań przeprowadzonych $\mathrm{w}$ bibliotekach amerykańskich przez Education Advisory Board, firmę cieszącą się największym doświadczeniem rozpoznawania praktyk akademickich, biznesowych, spraw studenckich, zdalnej edukacji oraz bibliotek w Ameryce Północnej. Dzięki bardzo szerokiemu gronu konsultantów i analityków biorących udział 
w przeprowadzeniu badań i opracowywaniu wniosków ta ciesząca się przeszło trzydziestoletnim doświadczeniem firma przedstawia raport przygotowujący środowisko zawodowe na nadchodzące zmiany.

Obszerna publikacja rezultatów badań przeprowadzonych na podstawie doświadczeń kilkudziesięciu najważniejszych amerykańskich bibliotek akademickich opatrzona została tytułem Redefinicja biblioteki akademickiej. Zarządzanie migracja do cyfrowych usług informacyjnych. Autorzy nie boją się stawiania trudnych pytań z punktu widzenia dotychczasowej organizacji pracy bibliotek i ich funkcji dla społeczeństwa informacyjnego. Wręcz przeciwnie, analizując zmiany na rynku wydawniczym, pojawianie się coraz nowocześniejszych technologii informatycznych oraz nowe preferencje czytelników ery cyfrowej, kreują obraz nowoczesnej biblioteki roku 2015, diametralnie odbiegający od dotychczasowych wyobrażeń. Zaznaczają też, że prognozy radykalnych zmian w bibliotekarstwie nie są co prawda nowe, ale rosnąca presja ograniczeń budżetowych bibliotek akademickich zmusi zarządzających do zmiany wcześniejszych strategii.

Istotną zmianą $\mathrm{w}$ funkcjonowaniu bibliotek akademickich będzie położenie większego nacisku na racjonalne wydatkowanie środków na gromadzenie zbiorów. Podkreśla się, że wskaźnik wielkości zasobu ustąpi miejsca wskaźnikowi faktycznego wykorzystania kolekcji. Pomocą w jego obliczaniu staną się moduly statystyczne komputerowych systemów bibliotecznych. To dzięki nim można będzie dogłębnie analizować trafność doboru literatury dla docelowej grupy użytkowników oraz tworzyć długookresową strategię gromadzenia. Dynamiczny wzrost liczby publikacji oraz ich wysokie ceny powodują, że bibliotek nie stać na zakup pozycji nieczytanych przez użytkowników. Brak zarejestrowanych udostępnień oznaczać będzie nieracjonalne wydawanie środków na zakupy i w konsekwencji niegospodarność instytucji. Problem ten jest też szeroko omawiany w odniesieniu do kolekcji zasobów elektronicznych. Autorzy opracowania zwracają uwagę, że kosztowne prenumeraty czasopism i baz, coraz powszechniejsze kupowanie dublujących się tytułów czasopism w pakietach oraz nieproporcjonalne do kosztów wykorzystywanie baz danych - nie dadzą się dłużej utrzymać w dobie fali kryzysu i ograniczeń budżetowych uczelni. Równocześnie prognozują $w$ tym zakresie zmiany: czasowe subskrypcje pozwolą wyeliminować powszechne dziś nietrafione zakupy, odważne negocjacje $\mathrm{z}$ wydawcami stworzą elastyczne kolekcje zasobów odpowiadające aktualnym preferencjom użytkowników, a władze uczelni, świadome konieczności utrzymywania pozycji w rankingach webometrycznych, zabiegać będą o tworzenie i rozwój bezpłatnych, otwartych zasobów wiedzy - repozytoriów. W podejmowaniu decyzji o zakupie literatury będzie się brało pod uwagę opinię nie tylko 
bibliotekarza, ale także - w coraz większym stopniu - samych użytkowników. Dziś na rynku wydawniczym pojawia się coraz więcej bardzo ciekawych ofert kierowanych do bibliotek, umożliwiających sprawdzenie zainteresowania książką przed jej zakupem przez instytucję. Zapis jednej z przykładowych licencji tej formy dostarczenia ebooków określa, że książka czytana ponad pięć minut obarcza bibliotekę kilkunastoprocentowym kosztem faktycznej ceny, zaś trzykrotne skorzystanie - koniecznością jej zakupu. Bibliotekarz przestaje mieć monopol na wiedzę - staje się dla użytkownika partnerem. W partnerstwie tym biblioteka dostarcza produkt $w$ postaci pewnego testowego pakietu, zaś czytelnik dostarcza informację o tym, z czego tak naprawdę chce korzystać i co biblioteka ma kupić.

Kwestią bardzo szeroko omawianą w książce jest nowe spojrzenie na użytkowników bibliotek. Jednym z kryteriów oceny jest badanie ich preferencji informacyjnych. Autorzy, przywołując badania OCLC z 2010 roku, wskazują że znaczna większość studentów rozpoczyna swoje poszukiwania naukowe $w$ wyszukiwarce internetowej, Wikipedii i Facebooku, nie zagląda natomiast w ogóle na stronę WWW swojej biblioteki. Równocześnie pracownicy naukowi co prawda przyznają się do korzystania $w$ pierwszej kolejności z licencjonowanych zasobów elektronicznych, ale kompletnie nie przychodzą po informacje do gmachu biblioteki. To samo badanie wskazuje, że słowo "biblioteka" nadal kojarzone jest wyłącznie $\mathrm{z}$ książką, a nie $\mathrm{z}$ informacją wiedzą lub usługą - stąd opór przed korzystaniem $\mathrm{z}$ materiałów bibliotecznych jako podstawowego zasobu informacji w epoce cyfrowej. Użytkownik biblioteki roku 2015 będzie doskonale zaznajomiony z nowoczesnymi technologiami - szczególnie bibliotecznymi usługami mobilnymi, które już dziś powszechnie pojawiają się na rynku. Dodatkowo będzie oczekiwał większości materiałów bibliotecznych w postaci cyfrowej, ponieważ stanowi to najszybszy i nieograniczony dostęp do źródeł i opracowań. Wydawać by się mogło, że użytkownik nowoczesnej biblioteki, biegły $\mathrm{w}$ zdobywaniu informacji $\mathrm{z}$ internetu, będzie potrzebował pomocy konsultantów bibliotecznych jako głównych weryfikatorów wiarygodności znalezionych treści. Autorzy są wprawdzie przekonani, że zważywszy na ogromną ilość materiału dostępnego w sieci, zdobywanie kompetencji informacyjnych jest dziś trudniejsze niż kiedykolwiek, ale obawiają się, że użytkownicy sami nie będą szukać wsparcia u konsultantów bibliotecznych. To bibliotekarze winni poszukiwać zarówno drogi dotarcia do użytkownika, jak również najodpowiedniejszej formy szkolenia czy instruktażu, najlepiej w przestrzeni wirtualnej, przez kursy e-learningowe czy tutoriale. Przeprowadzone badania wyraźnie wskazały, że 
biblioteka nie może ograniczać się wyłącznie do zajęć z przysposobienia bibliotecznego, ale jest zobligowana rozszerzać zakres tematyczny o kształtowanie umiejętności informacyjnych, wspierając przez to wydziały macierzystych uczelni.

Odrębny, bardzo interesujący dział publikacji stanowi analiza funkcji i znaczenia bibliotekarza. Ograniczenia budżetowe w bibliotekach hybrydowych już dziś przynoszą konsekwencje w postaci redukcji etatów, zaś nowe technologie już wkrótce przyniosą zmiany i eliminację nieracjonalnych zapisów dotyczących zakresów obowiązków personelu. Biblioteki bowiem nie będzie stać na równoczesne rozwijanie dwóch typów bibliotek - tradycyjnej i elektronicznej. W pewnym momencie zarządzający stanie przed koniecznością podjęcia decyzji strategicznej-czy ukierunkować instytucję na pozyskiwanie materiałów tradycyjnych i organizować duże powierzchnie magazynowe, czy też inwestować $w$ technologie i zdobywać fundusze na informatyzację. Analitycy wskazują na drugą opcję jako przyszłościową jednocześnie zalecają dyrekcjom określenie tych obszarów działalności, które można ograniczyć lub wyeliminować, i równoczesne rozpoczęcie przekwalifikowywania i migracji pracowników do nowych obowiązków. Jednym z najważniejszych usuniętych obszarów będzie tradycyjne opracowanie zbiorów. Rozwój katalogów centralnych, pozyskiwanie materiałów bibliotecznych z dołączonymi plikami opisów bibliograficznych, względnie podpisywanie umów z OCLC na udzielanie usługi opracowania, wydają się rozwiązaniami tańszymi, a przez to bardziej rentownymi dla instytucji. Jeden $z$ dyrektorów respondentów ujął to $w$ zdaniu, iż na świecie nie potrzeba tysiąca opisów tej samej książki. Możliwość ujednolicania metadanych, przesyłania ich protokołami, ich import do standaryzowanych systemów bibliotecznych - zwiastują konieczność przekwalifikowania głównie tej grupy bibliotekarzy. Nie da się utrzymać przez dłuższy czas tezy, że do opisu formalnego książki lub czasopisma potrzeba skomplikowanej wiedzy bibliotekarskiej. Równocześnie niewątpliwie cenne bibliotekarskie i dziedzinowe kwalifikacje katalogerów można będzie już niebawem wykorzystać chociażby w działalności edukacyjnej biblioteki, w prowadzonych przez nią szkoleniach, warsztatach, e-learningu lub dyżurach na platformach zdalnej komunikacji bibliotecznej. Na to winno się kłaść dziś szczególny nacisk. Kolejny przykład nowej funkcji bibliotekarza wskazują najnowsze standardy uczelni amerykańskich, gdzie w celu rejestracji wyników badań swoich naukowców wymaga się wdrożenia odpowiedniej infrastruktury informatycznej. Konieczność dokładnego organizowania, przechowywania i opisywania danych badawczych określona jest przez National Science Foundation i inne podmioty finansujące badania. Stąd można wysnuć 
wniosek, że bibliotekarze będą z pewnością bardziej angażować się w promowanie nowoczesnego publikowania $w$ open access, koordynować prace zmierzające do rozwoju uczelnianych repozytoriów wiedzy i pozyskiwać środki zewnętrzne na rozwój biblioteki, głównie przez sponsoring.

Nowoczesny model zarządzania biblioteką to przede wszystkim racjonalne wydatkowanie środków budżetowych, tworzenie dziedzinowych, regionalnych, a nawet międzynarodowych konsorcjów w celu ustalenia wspólnej strategii digitalizacji czy zakupów materiałów bibliotecznych i usług. Dodatkowo w polityce personalnej ważną odmianę będzie stanowiło dzielenie się etatami $\mathrm{z}$ wydziałami, w wyniku czego powstanie zespół specjalistów jednocześnie pracujących dla dobra biblioteki, jak również prowadzących zajęcia kierunkowe na uczelni i realizujących własne badania naukowe. Na pytanie, czy w nowoczesnej bibliotece będzie miejsce na bogate kolekcje zbiorów specjalnych, musi odpowiedzieć dyrekcja biblioteki. Autorzy sugeruja, że gromadzenie ich dla samego prestiżu i ograniczanie udostępniania są pozbawione sensu. W dobie rozwoju technologii informatycznych należy dołożyć wszelkich starań, by pozyskać środki na ich jak najszybszą digitalizację i udostępnianie kopii na platformach bibliotek cyfrowych. Wówczas koszty zakupu, konserwacji, przechowywania zwrócą się w postaci wykorzystania cyfrowej reprodukcji i spodziewanego przeprowadzania na ich przykładzie badań dla dobra nauki. Zarządzający musi też pamiętać, że przyszłość biblioteki jest związana $z$ rozwojem informatyzacji. Nie oznacza to $w$ żadnym razie sygnalizowania zmierzchu książek na nośniku tradycyjnym - print. Chodzi tu głównie o otwartość na treść $w$ formie elektronicznej i przygotowywanie się do jej gromadzenia, opracowywania, udostępniania i przechowywania. To żmudny proces, który wymaga sporych nakładów finansowych i osobowych na kolejną zmianę organizacji pracy, projektowanie i wdrażanie e-usług, zakup sprzętu komputerowego czy zapewnienie drożności sieci.

W nowoczesnej, przestronnej bibliotece akademickiej zmieni się też funkcja i znaczenie gmachu biblioteki. Po dokładnej analizie materiałów bibliotecznych zgromadzonych w magazynach i decyzjach na szczeblu regionalnych konsorcjów o deduplikacji przechowywanych tytułów część z nich - w celu ograniczania kosztów na konserwację i przechowywanie można będzie ubytkować. Budynek natomiast stanie się $w$ dużej mierze miejscem współpracy naukowców, studentów, przestrzenią pracy grupowej, ale także spotkań towarzyskich. Modułowe meble pozwalające na dowolną modyfikację, w zależności od potrzeb, bezprzewodowy internet, skanery, komputery, pomoc wykwalifikowanego personelu, a w niektórych bibliotekach zaplecze gastronomiczne - stworzą z biblioteki 
miejsce, gdzie chce się bywać i gdzie się bywa. Nieco w tyle pozostanie funkcja gmachu jako strażnika lokalnych kolekcji zasobów drukowanych. W tym wypadku grupą najbardziej zainteresowaną pozostaną pracownicy i studenci nauk historycznych i społecznych - według opinii ekspertów nieliczne kategorie czytelnicze, które zapełnią w przyszłości biblioteczne czytelnie.

Już od dawna bibliotekarze przyglądają się rozwiązaniom bibliotek amerykańskich przy wdrażaniu innowacji, które z czasem zaimplementowane $\mathrm{w}$ instytucjach polskich spotykają się $\mathrm{z}$ pełną satysfakcją użytkowników. Można więc śmiało polecić także i tę wnikliwą analizę, która w przystępny sposób zapowiada nieuchronną zmianę funkcji i znaczenia nowoczesnego bibliotekarstwa. Nie można bać się zmian, trzeba wykorzystać czas na rozwój własnych kompetencji, by już wkrótce, w cyfrowej erze bibliotekarstwa móc je wykorzystać. 